\title{
KESOPANAN TINDAK TUTUR MENYURUH DALAM BAHASA INDONESIA
}

\author{
Ngusman Abdul Manaf \\ Fakultas Bahasa dan Seni Universitas Negeri Padang \\ email: ngusman66@yahoo.com
}

\begin{abstract}
This study aims to describe verbal expressions by Indonesian speakers in the speech act of commanding politely in Indonesian. The data sources were Indonesian speech acts made by native speakers of Indonesian; they were collected through observations and interviews. The data were qualitatively analyzed using pragmatic theories. The results of the analysis show that there are two primary ways that native speakers of Indonesian use to perform the speech act of commanding politely. First, commands are performed by means of phatic expressions showing intimacy and appreciation. Second, they are performed through phatic expressions showing a minimization of force and burden.
\end{abstract}

Keywords: speech acts, phatic expression, language politeness

\section{PENDAHULUAN}

Muka atau citra diri pelaku tutur rawan jatuh dalam proses komunikasi. Pelaku tutur berusaha untuk menjaga muka masing-masing dalam komunikasi. Pelaku tutur mencakup penutur dan petutur. Penutur adalah orang yang bertutur dan petutur adalah orang yang diajak bertutur. Salah satu yang menyebabkan muka jatuh adalah tindak tutur. Menurut Brown dan Levinson (1983), tindak tutur direktif adalah tindak tutur yang potensial menjatuhkan muka. Oleh karena itu, tindak tutur direktif perlu dilengkapi dengan peranti penyelamat muka yang berupa kesopapanan (politeness) berbahasa. Artikel ini ditulis untuk menjelaskan cara-cara verbal yang dilakukan oleh penutur bahasa Indonesia untuk membentuk tindak tutur menyuruh dalam bahasa Indonesia yang santun

Searle (1976: 1-24) mengelompokkan tindak tutur menjadi lima jenis, yaitu tindak tutur representatif, direktif, ekspresif, komisif, dan deklarasi. Tin- dak tutur representatif adalah tindak tutur yang mengikat penuturnya atas kebenaran yang dituturkannya. Tindak tutur direktif adalah tindak tutur yang dilakukan agar petutur (orang yang diajak betutur) melaksanakan apa yang dikatakan oleh penutur. Tindak tutur ekspresif adalah tindak tutur yang dilakukan dengan maksud untuk menilai atau mengevaluasi hal yang disebutkan dalam tuturan. Tindak tutur komisif adalah tindak tutur yang mengikat penuturnya untuk melaksanakan hal yang disebutkan dalam tuturan. Tindak tutur Deklarasi adalah tindak tutur yang dilakukan dengan maksud menciptakan keadaan yang baru. Tindak tutur direktif mencakupi tindak tutur menyuruh, memohon, menyarankan, menghimbau, dan menasihati. Jadi, tindak tutur menyuruh adalah satu di antara lima bentuk tindak tutur direktif.

Menurut Brown dan Levinson (1987:61 -71), kesopanan berbahasa berdasar pada konsep muka (face) menurut Goffman. Muka mengacu kepada citra 
diri. Muka atau citra diri seseorang dapat jatuh. Oleh karena itu, muka perlu dijaga atau dilindungi. Agar muka tidak jatuh, muka perlu dijaga baik oleh pemilik muka itu sendiri maupun orang lain yang sedang sedang berkomunikasi. Salah satu faktor yang berpotensi untuk menjatuhkan muka pelaku tutur adalah tindak tutur. Agar tindak tutur tidak menjatuhkan muka pelaku tutur, tindak tutur perlu dilengkapi dengan peranti penyelamat muka yang berupa kesopapanan berbahasa. Muka dikelompokkan menjadi dua, yaitu muka positif dan muka negatif. Muka positif berupa kehendak diri untuk dinilai baik atas semua yang ada pada dirinya atau semua yang dimiliki. Muka negatif berupa kehendak diri untuk dibiarkan bebas melaksanakan apa yang dikehendaki. Perilaku yang santun adalah perilaku yang dapat memenuhi kehendak muka, baik muka positif maupun muka negatif. Karena muka yang perlu dilindungi ada dua jenis, kesopapanan berbahasa pun ada dua jenis, yaitu kesopapanan positif dan kesopanan negatif.

Teori kesopapanan Brown dan Levinson (1987) tidak dapat dilepaskan dari teori semantik kekuasaan dan semantik solidaritas (Brown dan Gilman, 1968:254-260). Brown dan Gilman menjelaskan bahwa penggunaan bentuk bahasa di dalam tindak tutur ditentukan oleh dua faktor semantik, yaitu semantik kekuasaan dan semantik solidaritas. Semantik kekuasaan (K) mengacu kepada otoritas atau wewenang yang dimiliki seseorang atas orang lain. Tingkat kekuasaan berwujud superioritas dari segi umur, pangkat, kekuatan, kebangsawanan, dan lainlain. Perbedaan kekuasaan antara lain dapat dapat dilihat pada contoh sebagai beriku: orang tua berkuas atas anaknya, guru berkuasa atas muridnya, majikan berkuasa atas buruhnya. Semantik solidaritas (S) mengacu kepada kedekatan atau keakraban seseorang kepada orang lain. Dua orang atau lebih yang mempunyai hubungn sosial yang dekat atau mempunyai jarak sosial yang minimal antara mereka dianggap mempunyai solidaritas yaang tinggi (+S). Sebaliknya orang yang sedikit mempunyai kedekatan sosial dinilai mempunyai solidaritas yang rendah (-S).

Brown dan Levinson menjelaskan bahwa pertimbangan yang dijadikan dasar pemilihan strategi kesopanan adalah faktor-faktor (1) jarak sosial antara penutur dan petutur (sosial distance $=\mathrm{D})$, (2) perbedaan kekuasaan antara penutur (speaker) dan petutur ( $a d-$ dresee) (power $=\mathrm{P})$, dan (3) status relatif jenis tindak tutur dalam kebudayaan yang bersangkutan (the absolute ranking of imposisition in the particular culture = R). Dalam kebudayaan tertentu ada bentuk tuturan tertentu yang dianggap santun dan ada pula bentuk tuturan tertentu yang dianggap tidak santun. Strategi kesopanan yang dipilih oleh penutur didasarkan atas bobot keterancaman muka penutur dan petutur (weightiness of the FTAx = Rx). Pertimbangan pemilihan strategi kesopapanan itu diformulasikan oleh Brown dan Levinson menjadi sebagai berikut: $\mathrm{Wx}=\mathrm{D}(\mathrm{S}, \mathrm{H})+\mathrm{P}$ $(\mathrm{H}, \mathrm{S})+\mathrm{Rx}$.

Penutur bahasa Indonesia di Sumatera Barat, memperhitungkan tingkat keterancaman muka berdasarkan dua hal, yaitu 1) perbedaan hubungan kekuasaan (power) $( \pm \mathrm{K})$ antara penutur dan petutur dan 2) tingkat hubungan keakraban atau solidaritas (solidarity) $( \pm S)$ antara penutur dan petutur. Faktor kekuasaan berupa perbedaan umur, perbedaan jabatan, perbedaan pangkat, dan perbedaan peran. Faktor solidaritas diniliai berdasarkan lamanya atau sebentarnya seseorang bergaul.

Atas dasar bobot keterancaman muka pelaku tutur, penutur memilih satu strategi bertutur dari lima strategi 
bertutur utama. Lima strategi bertutur itu adalah (1) bertutur secara terus terang atau tanpa basa-basi (bald on record); (2) bertutur dengan menggunakan basa-basi kesopanan posistif (positive politeness); (3) bertutur dengan menggunakan basa-basi kesopapanan negatif (negative politeness); (4) bertutur secara samar-samar (off record). (5) tidak menuturkan sesuatu (Don't do the FTA) atau diam.

Istilah positif dan negatif dalam bahasa Indonesia bermakna konotatif, yaitu positif berkonotasi 'baik' dan negatif berkonotasi 'buruk'. Sesungguhnya, istilah positif dan negatif menurut teori kesopanan berbahasa Brown dan Levinsen tidak mengoposisikan baik dan buruk. Brown dan levinson sekadar mengoposisikan karakteristik kehendak muka. Atas dasar pertimbangan rasa bahasa Indonesia, dalam artikel ini, digunakan istilah basa-basi penganjungan yang maksudnya adalah sama dengan istilah strategi basa-basi kesopapanan positif dan digunakan istilah basa-basi pembebasan yang maksudnya adalah sama dengan basa-basi kesopapanan negatif yang dimaksudkan oleh Brown dan Levinson. Tiga istilah strategi yang lain digunakan sebagaimana istilah Brown dan Levinson (1987). Perilaku santun berbahasa dapat dicapai dengan memilih strategi bertutur sesuai dengan tingkat keterancaman muka pelaku tutur.

Ada sejumlah orang yang telah menulis berkaitan dengan masalah yang ditulis dalam artikel ini, Leech (1983), Brown dan Levinson (1987), Blum-Kulka (1987), Gunarwan (1992), (1994), dan (2000), Ibrahim, 1996, Aziz (2002), Mualimin (2003), Manaf (2005). Perbedaan tulisan ini dengan tulisan sebelumnya yang telah disebutkan itu adalah terletak pada fokus tulisan dan penutur yang dibahas. Masalah yang dikaji dalam tulisan ini difokuskan pada penyelamatan muka dalam tindak tutur menyuruh yang dilakukan oleh penutur bahasa Indonesia anggota etnis Minangkabau.

\section{METODE}

Data yang digunakan dalam tulisan ini adalah tindak tutur dalam bahasa Indonesia yang dilakukan oleh penutur bahasa Indonesia dalam komunikasi sehari-hari. Sumber data tulisan ini penutur adalah penutur asli bahasa Indonesia dari berbagai suku di Indonesia yang kebetulan berdomisili di Kota Padang Sumatera Barat. Penutur bahasa Indonesia yang menjadi sumber data penelitian mencakup penutur yang berjenis kelamin laki-laki dan perempuan, berpendidikan rendah, menengah, dan tinggi, bekerja sebagai ibu rumah tangga, tukang, pedagang, pegawai kantor, guru, murid, mahasiswa, dan dosen. Data tulisan ini dikumpulkan dengan teknik pengamatan dan wawancara pada tahun 2009 sampai dengan 2010.

Data tulisan ini dianalisis dengan cara berikut ini. Data yang sudah terkumpul diidentifikasi untuk mendapatkan tindak tutur direktif dan jenis strategi kesopanan berbahasa. Tindak tutur direktif itu diklasifikasikan berdasarkan jenis strategi kesopapanan berbahasa yang digunakan untuk merealisaikan tindak tutur. Kalimat yang digunakan untuk mengungkapkan tindak tutur dihubung-hubungkan dengan konteks situasi tutur untuk mengetahui maksud penutur. Hubungan kalimat yang digunakan untuk mengungkapkan tindak tutur dengan konteks situasi tutur dan maksud penutur yang berulang ditafsirkan untuk merumuskan prinsipprinsip kesopapanan berbahasa Indonesia dalam tindak tutur menyuruh

\section{HASIL DAN PEMBAHASAN}

Berdasarkan data yang dijadikan bahan untuk penulisan artikel ini, ada dua cara utama yang dilakukan oleh pe- 
nutur bahasa Indonesia untuk bertindak tutur menyuruh dalam bahasa Indonesia secara sopan, yaitu (1) dengan basabasi pengkraban dan penganjungan dan (2) dengan basa-basi peminimalan paksaan dan beban. Setiap cara berbasa-basi itu diuraikan satu per satu berikut ini.

\section{Perilaku Sopan dalam Tindak TuturMe- nyuruh dengan Basa-basi Pengakrab- an dan Penganjungan}

Cara berperilaku sopan dalam tindak tutur menyuruh dengan basa-basi pengakraban dan penganjungan adalah sama dengan kesopapanan positif yang dimaksudkan oleh Brown dan levinson (1987). Basa-basi pengakraban dan penganjungan direalisasikan dalam bentuk (1) menggunakan penanda identitas sebagai anggota kelompok yang sama, (2) melibatkan penutur dan petutur dalam kegiatan yang sama, (3) mencari kesepakatan, (4) saling membantu, dan (5) sambil bergurau. Setiap cara basabasi pengakraban dan penganjungan itu diuraikan satu per satu berikut ini.

Sopan dalam tindak tutur menyuruh dengan cara menggunakan penanda identitas dari kelompok yang sama adalah seperti contoh (1).

(1) A: Selera kita sama, ya Pak. Sudah makan, tetapi belum merokok, terasa belum selesai.

B: Ya, Pak.

A: Kita cari tempat yang lebih nyaman untuk merokok, Pak!

Tindak tutur (1) dilakukan oleh dua orang guru laki-laki peserta pendidikan dan latihan sertifikasi guru pada saat istirahat siang. Dua orang guru itu ada di sebuah ruangan tertutup yang di dalamnya banyak guru perempuan. A menyuruh B untuk merokok di tempat lain dengan berbasa-basi menyatakan mempunyai kesenangan yang sama untuk meminimalkan jatuhnya muka dengan mengatakan, "selera kita sama". Kemudian, A melanjutkan pembicaraannya dengan mengatakan, "Kita cari tempat yang lebih nyaman untuk merokok, Pak!" Ungkapan selera kita sama menunjukkan bahwa antara penutur dan petutur adalah dari kelompok yang sama. Di samping itu, kata kita juga mengandung maksud bahwa penutur (yang berbicara) dan petutur (orang yang diajak bicara) tercakup di dalamnya. Dengan tindak tutur itu, petutur terkesan diakrabi, diperlakukan sama dengan yang lain (tidak dikucilkan) dan diperlakukan dengan ramah sehingga tindak tutur itu dirasakan santun.

Cara berperilaku sopan dalam tindak tutur menyuruh dengan cara basa-basi mengakrabkan dan penganjungan dalam bentuk penutur dan petutur terlibat dalam kegiatan yang sama adalah seperti contoh (2).

(2) (a) Kita geser almari ini ke samping!

(b) Ayo, bantu ibu memasukkan buku ke dalam almari!

(c) Mari kita angkat meja ini bersama-sama!

Tindak tutur (2a) dilakukan oleh Ketua Jurusan bersama dengan dosen yang menata ruangan dosen. Tindak tutur (2b) dilakukan oleh seorang guru SD yang menyuruh muridnya untuk memasukkan buku ke dalam almari. Tindak tutur (2c) dilakukan oleh seorang murid kepada kawannya yang sama-sama bergotong royong membersihkan ruangan. Penggunaan kata kita dalam tindak tutur (2a), ayo dalam tuturan (2b), dan mari dalam tindak tutur (2c) menunjukkan bahwa penutur mengajak petutur untuk bersama-sama melakukan kegiatan yang dinyatakan oleh penutur. Kesediaan penutur untuk melakukan kegiatan secara bersamasama dengan petutur dapat dipahami sebagai usaha penutur membaur atau 
menyatu dalam satu kelompok dengan petutur sehingga ada alasan bagi penutur untuk menyuruh petutur untuk melakukan sesuatu. Di samping itu, kesediaan penutur menyatu di dalam satu kelompok dengan petutur juga dapat dipahami penutur menerima dan menghargai petutur yang menimbulkan efek pelunakan daya ilokusi sehingga tindak tutur itu dirasakan santun.

Cara berperilaku sopan dalam tindak tutur menyuruh dengan basabasi pengakraban dan penganjungan dalam bentuk mencari kesepakan adalah seperti contoh (3).

(3) (a) Tolong antarkan saya, ya Kak?

(b) Kita setuju kemping dilaksanakan pada bulan Oktober, kan?

(c) Bagaimana kalau setiap hari Jumat dari pukul 07.00 s.d. 13.00 dikosongkan dari kegiatan perkuliahan dan diisi dengan kegiatan olah raga, keagamaan, dan silaturahim.

Tindak tutur (3a) dilakukan oleh seorang mahasiswi yunior kepada mahasiswi senior yang tinggal di satu rumah kos. Tindak tutur (3b) dilakukan oleh Ketua Badan Ekskutif Mahasiswa kepada peserta rapat dalam sebuah rapat. Tindak tutur (3c) diucapkan oleh seorang dosen kepada ketua Jurusan pada saat rapat jurusan. Penggunaan kata ya dalam tuturan (2a), kan dalam tuturan (2b), dan bagaiman kalau dalam tutran (2c) menunjukkan usaha penutur menghargai petutur dengan jalan penutur meminta persetujuan atau meminta pendapat yang terkait dengan petutur. Tindakan penutur meminta persetujuan dengan petutur menimbulkan efek pelunakan daya ilokusi sehingga meminimalkan paksaan. Di samping itu, penggunaan bentuk ya, kan, dan bagaimana kalau memberikan kesempatan petutur untuk menolak suruhan jika petutur tidak bersedia. Tindak tutur yang memberi kesempatan kepada petutur untuk menolak sebuah suruhan juga memperlunak daya ilokusi, yaitu meminimalkan paksaan sehingga tindak tutur itu dirasakan santun.

Cara berperilaku sopan dalam tindak tutur menyuruh dengan basabasi pengakraban dan penganjungan dalam bentuk basa-basi saling membantu adalah seperti contoh (4).

(4) (a) Dik, cuci piring ini! Biar Kakak yang masak!

(b) Saya mengumpulkan data dan Pak Usman mengolahnya!

Tindak tutur (4a) dilakukan oleh seorang mahasiswi yang lebih senior kepada kawannya yang lebih muda ketika sedang memasak. Mereka tinggal di satu kamar di sebuah rumah kos. Untuk makan sehari-hari, mereka beriur uang untuk membeli bahan makanan dan mereka memasakknya secara bersamasama. Tindak tutur (4b) diucapkan oleh seorang anggota tim dalam sebuah penelitian kepada kawannya yang juga merupakan anggota tim itu. Basa-basi saling membantu di dalam tindak tutur (4a) terlihat dari petutur (mitra tutur) disuruh mencuci piring dan penutur memasak nasi. Basa-basa di dalam tindak tutur (4b) terlihat dari tindakan penutur mengumpulkan data dan petutur disuruh mengolah data. Perilaku saling membantu antara penutur dan petutur menunjukkan keakraban dan rasa saling menghargai menimbulkan efek pelunakan daya ilokusi sehingga sehingga tindak tutur itu terasa santun. Di samping itu, karena penutur juga membantu mengatasi kesulitan petutur, penutur menyuruh petutur untuk melakukan sesuatu adalah dapat diterima.

Cara berprilaku sopan dalam tindak tutur menyuruh dengan basa-basi 
pengakraban diri dan penganjungan adalah seperti contoh (5).

(5) (a) Bung-bung, adik saya bagaimana? Dia belum dikasih surat keterangan. Jangan lain-lain saja yang dikerjakan! Mentang-mentang jadi pejabat. (Penutur tidak serius dan sambil memberikan sebatang rokok kepada petutur. Petutur tersenyum.)

(b) Hei Komandan, seperti orang pening saja. Kerjakan ini cepat! (Penutur tidak serius. Penutur memberikan sebuah kartu keluarga kepada petutur untuk dibuatkan Kartu Tanda Penduduk (KTP). Pada saat melaksanakan tindak tutur ini, penutur memberikan sebungkus rokok kepada petutur. Petutur tertawa pelan. Petutur membuka bungkus rokok dan mengambil sebatang lalu diletakan di mulutnya. Penutur menghidupkan korek api dan menolong membakar ujung rokok yang siap untuk dihisap petutur.)

Tindak tutur (5a) diucapkan oleh seorang dosen kepada kawannya yang juga dosen yang umurnya sebaya, hubungannya akrab, dan kawannya itu menjabat sebagai pembantu dekan di sebuah fakultas. Mereka bertemu di di sebuah ruangan santai. Tuturan (5b) diucapkan oleh seorang warga sebuah kelurahan kepada seorang pegawai kelurahan di sebuah kantor lurah. Mereka sebaya dan akrab. Sikap tidak serius penutur kepada petutur di dalam tindak tutur (5a) dan (5b) dan penggunaan sapaan bung dan komandan adalah bentuk gurauan penutur kepada petutur. Penutur menyapa petutur dengan sapaan bung dalam tindak tutur (5a) dan sapaan komandan dan dalam tuturan (5b) adalah tidak sesuai dengan keadaan yang sebenarnya. Kata sapaan bung lazim diguna- kan untuk menyapa seseorang yang karismatik, misalnya Bung Tomo (pejuang kemerdekaan), Bung Karno (pejuang kemerdekaan dan tokoh revolusi). Di dalam tuturan (5a) kata bung digunakan untuk menyapa seorang pegawai tata usaha yang biasa-biasa saja. Di dalam tuturan (5b), kata komandan digunakan untuk menyapa seorang pegawai kelurahan yang biasa melayani pembuatan KTP. Bentuk gurauan dalam dua tindak tutur itu juga ditandai dengan tindak nonverbal, yaitu memberikan rokok dan membantu menyulut rokok.

Bergurau dapat dipahami sebagai usaha penutur mengurangi jarak sosial antara penutur dan petutur. Lebih dari itu, penutur mau bergurau dengan petutur dapat dipahami sebagai penutur menerima petutur sebagai satu kelompok, penutur tidak mengucilkan petutur, penutur tidak menganggap petutur sebagai orang asing, dan bahkan penutur dapat dinilai menghargai petutur atau menganjungkan petutur. Perilaku positif kepada petutur seperti itu menyenangkan hati petutur sehingga tindak tutur itu dirasakan santun. Basabasi dalam bentuk bergurau cenderung digunakan dalam konteks pelaku tutur berusia sebaya, sudah akrab, dan dalam situasi nonformal.

\section{Perilaku Santun dalam Tindak Tutur Menyuruh dengan Basa-basi Pemini- malan Paksaan dan Beban}

Basa-basi peminimalan paksaan dan beban adalah usaha untuk membangun kesan bahwa penutur tidak memaksa atau membebani petutur atau penutur tidak menghalang-halangi petutur untuk melakukan apa yang diinginkannya. Basa-basi peminimalan paksaan dan beban ini adalah sama dengan kesopapanan negatif menurut Brown dan Levinson (1987). Sopan dalam tindak tutur menyuruh dengan cara basa-basi peminimalan paksaan atau 
beban dilakukan dengan (1) menyuruh secara tidak langsung, (2) menggunakan pagar, (3) menyuruh dengan syarat (4) meminimalkan permintaan kepada petutur, (5) meminta maaf, dan (6) menyuruh dalam bentuk aturan umum. Setiap cara basa-basi peminimalan paksaan dan beban diuraikan satu per satu berikut ini.

Cara berperilaku sopan dalam tindak tutur menyuruh dengan $b a s a-b a-$ si peminimalan paksaan dan beban dalam bentuk menyuruh secara tidak langsung dilakukan dengan beberapa cara, yaitu (1) pertanyaan, (2) saran, (3) pemberitahuan. Setiap cara penyuruhan secara tidak langsung itu diuraikan satu persatu berikut ini.

Cara berperilaku sopan dalam tindak tutur menyuruh dengan cara menyuruh secara tidak langsung berupa menyuruh dalam bentuk pertanyaan adalah seperti contoh (6).

(6) (a) Apakah Bapak dapat mencarikan buku Permainan Pembelajaran Bahasa?

(b) Bisakah Buk Novia mengirimkan nomor HP Pak zulfadly kepada saya?

(c) Maukah Kak Ani menemani saya membeli komputer?

(d) Apakah Erman bersedia meminjamkan mobil untuk acara keluarga kami?

Tindak tutur (6a) diucapkan oleh seorang mahasiswa kepada petugas perpustakaan. Petugas perpustakaan itu usianya lebih tua dan belum akrab. Tindak tutur itu dilakukan diperpustakaan tepatnya di bagian peminjaman dan pengembalian buku. Tindak tutur (6b) dilakukan oleh seorang dosen yang lebih muda kepada dosen yang lebih tua. Hubungan kedua dosen itu akrab, tetapi saling menyegani. Pembica- raan dilakukan lewat HP. Tindak tutur (6c) dilakukan oleh seorang mahasiswi kepada kawannya yang lebih senior. Hubungan penutur dan petutur adalah sudah akrab. Tindak tutur itu dilakukan di rumah kos. Tindak tutur (6d) dilaksanakan oleh seseorang kepada tetangganya yang usianya lebih muda tetapi sudah akrab.

Tindak tutur menyuruh (6a) dan (6b) dilaksanakan dengan menggunakan pertanyaan yang menanyakan kemampuan atau kesanggupan yang ditandai dengan ungkapan apakah ... dapat dalam tindak tutur (6a) dan ungkapan bisakah... dalam tindak tutuur (6b). Tindak tutur menyuruh (6c) dan (6d) dilaksanakan dengan menggunakan pertanyaan yang menanyakan kemauan atau kesediaan yang ditandai dengan ungkapan maukah ... dalam tindak tutur (6c) atau bersediakah ... dalam tindak tutur (6c). Tindak tutur (6a) merupakan alih-alih dari suruhan langsung carikan buku Permainan pembelajaran bahasa, Pak. Tindak tutur (6b) merupakan alih-alih dari suruhan langsung Buk Novia, kirimkan nomor HP Pak Zulfadly kepada saya. Tindak tutur (6c) merupakan alih-alih dari suruhan langsung Kak Ani, temani saya membeli komputer. Tindak tutur (6d) merupakan alih-alih dari suruhan langsung pinjamkan mobilmu untuk acara keluarga kami, Erman.

Penutur tidak menggunakan bentuk suruhan langsung karena suruhan langsung terkesan memaksa. Kesan memaksa itu mengakibatkan tindak tutur dirasakan tidak santun oleh petutur. Sebaliknya, penutur memilih suruhan secara tidak langsung dalam bentuk bertanya yang berdampak pada peminimalan paksaan, yaitu penutur seolaholah tidak menyuruh atau solah-olah sekadar bertanya. Karena tindak tutur itu dapat ditafsirkan sebagai bertanya, berarti tidak ada orang yang menyuruh dan tidak ada yang menyuruh. Oleh 
karena itu, petutur ada alasan untuk tidak melaksanakan suruhan itu dan penutur juga tidak merasa malu ketika suruhannya tidak dilaksanakan oleh petutur. Penyampaian maksud penutur kepada petutur secara tidak langsung itu menimbulkan efek pelunakan daya ilokusi, yaitu petutur terkesan tidak dipaksa sehingga tindak tutur itu dirasakan santun.

Cara berperilaku sopan dalam tindak tutur menyuruh dengan cara menyuruh secara tidak langsung berupa penyuruhan dalam bentuk saran adalah seperti contoh (7).

(7) (a) Warga RT 02 hendaknya menyediakan waktu satu hari dalam dua bulan untuk gotong royong.

(b) Bagaimana kalau fondasi bangunan mesjid ini dibuat lebih kuat?

Tindak tutur (7a) dilakukan oleh seorang ketua RT kepada warganya yang hadir pada rapat RT. Tuturan (7b) dilakukan oleh salah seorang jemaah mesjid kepada seluruh jemaah mesjid yang hadir dalam rapat pembangunan kembali sebuah mesjid yang rusak berat karena gempa. Tindak tutur menyuruh (7a) dan (7b) dilakukan dalam bentuk permberian saran, yang ditandai dengan penggunaan ungkapan ... hendaknya ... dalam tindak tutur (7a) dan ungkapan bagaimana kalau ... dalam tindak tutur (7b). Tindak tutur (7a) merupakan alihalih dari suruhan langsung warga RT 02 harus menyediakan waktu satu hari dalam dua bulan untuk gotong royong. Tindak tutur (7b) merupakan alih-alih dari suruhan langsung fondasi mesjid buat lebih kuat.

Penutur tidak menggunakan bentuk suruhan langsung karena suruhan langsung terkesan memaksa. Kesan memaksa itu mengakibatkan tindak tutur dirasakan tidak santun oleh petutur. Oleh karena itu, penutur memilih suru- han secara tidak langsung dalam bentuk saran yang berdampak pada peminimalan paksaan, yaitu penutur seolaholah tidak menyuruh atau solah-olah sekadar memberi saran. Karena tindak tutur itu dapat ditafsirkan sebagai sekadar saran, berarti tidak ada orang yang menyuruh dan tidak ada yang menyuruh. Oleh karena itu, petutur ada alasan untuk tidak melaksanakan suruhan itu dan penutur juga tidak merasa malu ketika suruhannya tidak dilaksanakan oleh petutur. Penyampaian maksud penutur kepada petutur dalam bentuk saran yang ditandai dengan ungkapan hendaknya dan bahgaimana kalau atau sebaiknya menimbulkan efek pelunakan daya ilokusi, yaitu petutur terkesan tidak dipaksa sehingga tindak tutur itu dirasakan santun.

Cara berperilaku sopan dalam tindak tutur menyuruh dengan cara menyuruh secara tidak langsung berupa penyuruhan dalam bentuk pemberitahuan adalah seperti contoh (8).

(8) (a) Tempat ini bebas asap rokok.

(b) Ruangan ini gelap.

(c) Jal, sekarang sudah tanggal 20.

Tindak tutur (8a) dilakukan atas nama pimpinan kantor terhadap semua orang yang berkunjung di kantor itu. Tindak tutur ini diungkapkan dalam bentuk tulis yang dipasang di sebuah dinding ruangan. Tindak tutur $(8 b)$ dilakukan oleh seorang dosen kepada mahasiswa yang mengikuti perkulihan. Ruang perkuliahan itu gelap karena mendung. Tindak tutur (8c) dilakukan oleh seorang ibu kos kepada seorang mahasiswa laki-laki yang kos di tempat ibu kos itu, tetapi sampai tanggal 20 bulan yang sedang berjalan mahasiswa itu belum membayar kos. Penutur dalam tindak tutur (8a) bermaksud untuk menyuruh semua orang yang ada di kantor itu untuk tidak merokok. Penutur dalam 
tindak tutur ( $8 b$ ) bermaksud untuk menyuruh untuk tidak merokok di ruangan itu. Tindak tutur (8a) dapat merupakan alih-alih suruhan langsung, misalnya semua orang yang ada di kantor ini dilarang merokok di ruangan ini! Penutur dalam tindak tutur $(8 b)$ bermaksud untuk menyuruh petutur untuk menghidupkan lampu, tetapi dinyatakan dalam bentuk pemberitahuan atau pernyataan ruangan ini gelap. Tindak tutur (8b) dapat merupakan alih-alih suruhan langsung, misalnya karena ruangan ini gelap, hidupkanlah lampu. Penutur dalam tindak tutur (8c) bermaksud menyuruh petutur untuk membayar uang kos, tetapi penyuruhan itu dilakukan dalam bentuk pernyataan atau pemberitahuan Jal, sekarang sudah tanggal 20. Tindak tutur (8c) dapat merupakan alih-alih suruhan langsung, misalnya Jal, bayarlah uang kos karena sekarang sudah tanggal 20.

Penutur tidak menggunakan bentuk suruhan langsung karena suruhan langsung terkesan memaksa. Kesan memaksa itu mengakibatkan tindak tutur dirasakan tidak santun oleh petutur. Oleh karena itu, penutur memilih suruhan secara tidak langsung dalam bentuk ungkapan pernyataan atau pemberitahuan yang berdampak pada peminimalan paksaan, yaitu penutur seolaholah tidak menyuruh atau solah-olah sekadar memberi tahu. Karena tindak tutur itu dapat ditafsirkan sebagai pemberitahuan, berarti tidak ada orang yang menyuruh dan tidak ada yang menyuruh. Oleh karena itu, petutur ada alasan untuk tidak melaksanakan suruhan itu dan penutur juga tidak merasa malu ketika suruhannya tidak dilaksanakan oleh petutur. Penyampaian maksud penutur kepada petutur secara tidak langsung itu menimbulkan efek pelunakan daya ilokusi, yaitu petutur tidak terkesan dipaksa sehingga tindak tutur itu dirasakan santun.
Cara berperilaku sopan dalam tindak tutur menyuruh dengan basabasi peminimalan paksaan dan beban berupa penyuruhan dalam bentuk penggunaan pagar adalah seperti contoh (9).

(9) (a) Saya sebenarnya ingin Bapak memberikan upah saya lebih awal khusus bulan ini karena anak saya baru masuk SMA.

(b) Saya sesungguhnya berharap dapat memfoto kopi hasil penelitian Bapak tentang kesopapanan berbahasa Indonesia, tetapi saya takut merepotkan Bapak.

Tindak tutur (9a) dilakukan oleh seorang tukang kepada seseorang yang memperkerjakannya. Tuturan (9b) dilakukan oleh salah seorang mahasiswa kepada dosennya. Tindak tutur menyuruh (9a) dan (9b) dilakukan dalam bentuk penggunaan pagar, yang ditandai dengan penggunaan ungkapan sebenarnya ingin dalam tindak tutur (9a) dan ungkapan sesungguhnya berharap dapat dalam tindak tutur (9b).

Penutur dalam tindak tutur (9a) bermaksud untuk menyuruh orang yang memperkerjakannya agar membayarkan upahnya pada awal bulan. Penutur dalam tindak tutur (9b) bermaksud untuk meminta dosennya agar meminjamkan hasil penelitiannya. Tindak tutur (9a) merupakan alih-alih dari suruhan langsung Pak bayarkanlah upah saya pada awal bulan khusus bulan ini karena anak saya baru masuk SMA. Pinjamkanlah hasil penelitian Bapak kepada saya! Tindak tutur (9b) merupakan alihalih dari suruhan langsung pinjamkanlah hasil penelitian Bapak kepada saya!

Penutur tidak menggunakan bentuk suruhan tanpa basa-basi karena suruhan tanpa basa-basi terkesan memaksa. Kesan memaksa itu mengakibatkan tindak tutur dirasakan tidak santun oleh petutur. Oleh karena itu, penutur 
memilih suruhan denngan basa-basi dalam bentuk penggunaan pagar yang berdampak pada peminimalan paksaan, yaitu penutur seolah-olah tidak menyuruh, sekadar menyampaikan keinginannya atau menyampaikan harapan. Penyampaian maksud penutur kepada petutur dengan basa-basi itu menimbulkan efek pelunakan daya ilokusi, yaitu petutur tidak terkesan dipaksa sehingga tindak tutur itu dirasakan santun.

Cara berperilaku sopan dalam tindak tutur menyuruh dengan strategi basa-basi peminimalan paksaan dan beban berupa permintaan bersyarat adalah seperti contoh (10).

(10) (a) Jika Bapak ada waktu, kita pergi ke Pesisir Selatan melihat sapi korban, Pak!

(b) Kalau Ibu tidak keberatan, pengurus mesjid meminta Ibu menjadi donatur tetap Taman Pendidikan al-Qur'an Mesjid alManar!

(c) Jika Bapak ada kesempatan dan mau, kami ingin Bapak berkunjung ke Mentawai untuk melihat keadaan sekolah kami setelah peristiwa Gempa dan tsunami.

Tindak tutur (10a) dilakukan oleh seorang Panitia Hari Raya Qurban kepada salah seorang pengurus mesjid. Tindak tutur (10b) dilakukan oleh seorang pengurus Taman Pengajian al Qur'an kepada seorang jemaah mesjid. Tindak tutur (10c) dilakukan oleh seorang guru yang berasal dari Mentawai kepada seorang pejabat di Dinas Kementerian Pendidikan Nasional Kota Padang. Tindak tutur menyuruh (10a), (10b), dan (10c) dilakukan dalam bentuk permintaan bersyarat yang ditandai dengan penggunaan ungkapan jika $B a-$ pak ada waktu dalam tindak tutur (10a), ungkapan kalau Ibu tidak keberatan dalam tindak tutur (10b), dan ungkapan jika
Bapak ada kesempatan dan mau dalam tindak tutur (10c).

Dalam tindak tutur (10a), penutur bermaksud menyuruh seorang pengurus mesjid ikut menengok calon sapi korban di daerah Pesisir Selatan. Penutur dalam tindak tutur (9b) bermaksud untuk meminta seorang jemaah mesjid menjadi donatur Taman Pendidikan al Qur'an. Penutur dalam tindak (10c) meminta salah seorang pejabat di Kantor Dinas Kementererian Pendidikan Nasional Kota Padang untuk datang ke Mmentawai menengok sekolah yang rusak karena tunami. Tindak tutur (10a) merupakan alih-alih dari suruhan langsung pergilah menegok calon sapi korban di Pesisir Selatan, Pak. Tindak tutur (10b) merupakan alih-alih dari suruhan langsung Jadilah donatur tetap Taman Pendidikan al Qur'an mesjid al Manar, Bu. Tindak tutur (10c) merupakan alih-alih suruhan langsung Pak datanglah ke Mentawai menengok sekolah kami yang rusak karena tsunami.

Penutur tidak menggunakan bentuk suruhan tanpa basa-basi karena suruhan tanpa basa-basi terkesan memaksa. Kesan memaksa itu mengakibatkan tindak tutur dirasakan tidak santun oleh petutur. Sebaliknya, penutur memilih suruhan dengan basa-basi dalam bentuk permintaan bersyarat, misalnya jika Bapak ada waktu, kalau Ibu tidak keberatan, jika Bapak ada kesempatan dan mau berdampak pada peminimalan paksaan. Permintaan bersyarat ini memberikan alternatif pilihan kepada petutur untuk melaksanakan atau tidak melaksakan apa yang dinyatakan penutur. Petutur tidak perlu melaksanakan apa yang dinyatakan oleh penutur jika syarat tidak terpenuhi atau keadaan tidak memungkinkan. Petutur melaksanakan apa yang dinyatakan penutur jika persyaratan terpenuhi atau keadaan memungkinkan. Pemberian alternatif pilihan untuk melaksanakan atau tidak melaksanakan 
apa yang dinyatakan oleh penutur menimbulkan efek pelunakan daya ilokusi, yaitu petutur terkesan tidak dipaksa sehingga tindak tutur itu dirasakan santun.

Cara berperilaku sopan dalam tindak tutur menyuruh dengan strategi basa-basi meminimalkan pakasaan dan beban berupa meminimalkan permintaan kepada petutur adalah seperti contoh (11).

\section{(11) (a) Geser sedikit, Dik!}

(b) Pak saya minta waktu sebentar untuk menyampaikan berita duka dan pengumpulan dana!

(c) Tolong ketikkan satu, Pak!

Tindak tutur (11a) dilakukan oleh seorang penumpang sebuah mobil angkutan kota kepada salah seorang penumpang penumpang itu. Tindak tutur (11b) dilakukan oleh seorang mahasiswa kepada dosennya di kelas untuk menyampaikan berita duka dan pegumpulan dana sosial. Tindak tutur (11c) dilakukan oleh seorang guru kepada seorang pegawai tata usaha di sebuah sekolah. Tindak tutur menyuruh (11a), (11b), dan (11c) dilakukan dalam bentuk peminimalan permintaan kepada petutur yang ditandai dengan penggunaan ungkapan geser sedikit dalam tindak tutur (11a), ungkapan minta waktu sebentar dalam tindak tutur (11b), dan ungkapan ketikkan satu dalam tindak tutur (11c).

Dalam tindak tutur (11a), penutur bermaksud menyuruh salah seorang sesama penumpang untuk bergeser karena penutur itu juga akan ikut duduk. Penutur dalam tindak tutur (11b) bermaksud untuk meminta kepada dosen yang mengajar di kelas agar memberi izin kepada mahasiswa untuk penyampaian berita duka dan pengumpulan dana sosial. Penutur dalam tindak tutur (11c) bermaksud meminta tolong kepada seorang pegawai tata usaha di seko- lah itu untuk mengetikkan daftar kredit poin untuk kenaikan pangkat. Tindak tutur (11a) merupakan alih-alih dari suruhan tanpa basa-basi kamu bergeser ke tepi. Tindak tutur (11b) merupakan alihalih dari suruhan tanpa basa-basi berilah izin kepada kami untuk menyampaikan berita duka dan pengumpulan dana sosial. Tindak tutur (11c) merupakan alih-alih suruhan tanpa basa-basi ketikkan daftar kredit poin saya ini.

Penutur tidak menggunakan bentuk suruhan tanpa basa-basi, karena suruhan tanpa basa-basi terkesan membebani petutur. Kesan membebani itu mengakibatkan tindak tutur dirasakan kurang santun oleh petutur. Sebaliknya, penutur memilih suruhan dengan basabasi peminimalan permintaan kepada petutur, misalnya geser sedikit, minta waktu sebentar, dan ketikkan satu berdampak pada peminimalan beban kepada petutur. Peminimalan beban ini memberikan kesan penutur berusaha tidak merepotkan petutur. Usaha penutur untuk tidak merepotkan petutur menimbulkan efek pelunakan daya ilokusi sehingga tindak tutur itu dirasakan santun.

Cara berperilaku sopan dalam tindak tutur menyuruh dengan strategi basa-basi peminimalan paksaan dan beban berupa menyuruh disertai dengan meminta maaf adalah seperti contoh (12).

(12) (a) Maaf Pak, mohon mobilnya di Parkir di tempat yang disediakan!

(b) Maaf Buk, saya terlambat karena Ban sepeda motor saya bocor.

(c) Maaf, tolong TV-nya kecilkan, Dik!

(d) Permisi Pak, sepeda motornya dipindahkan. Saya mau menggelar barang dagangan.

Tindak tutur (12a) dilakukan oleh seorang satpam kepada seorang tamu yang memarkir kendaraannya di lokasi 
sebuah kantor. Tindak tutur (12b) dilakukan oleh seorang mahasiswa yang terlambat masuk kuliah kepada dosennya. Tindak tutur (12c) dilakukan oleh seorang mahasiswa senior kepada mahasiswa yunior yang tinggal di satu rumah kos. Tindak tutur (12d) dilakukan oleh seorang pedagang kaki lima kepada orang yang memarkir sepeda motornya di tempat penutur itu berdagang. Tindak tutur menyuruh (12a), (12b), (12c), dan (12d) dilakukan dalam bentuk meminta maaf atau meminta izin yang ditandai dengan penggunaan ungkapan maaf dalam tindak tutur (12a), (12b), (12c), dan ungkapan permisi dalam tindak tutur (12d).

Dalam tindak tutur (12a), penutur bermaksud menyuruh seorang yang berkunjung di kantor untuk memarkir mobilnya di tempat yang sudah disediakan. Dalam tindak tutur (12b), penutur yaitu mahasiswa yang terlambat masuk kuliah meminta izin untuk ikut kuliah. Dalam tindak tutur (12c), penutur bermaksud meyuruh temanya yang lebih muda untuk memelankan TV. Dalam tindak tutur (12d), penutur bermaksud menyuruh orang yang memarkir sepeda motor di tempat penutur menggelar dagangannya untuk memindahkan sepeda motornya.

Penutur menggunakan basa-basi meminta maaf atau minta izin kepada petutur, yaitu dengan ungkapan maaf atau permisi membentuk kesan penutur mengaku sebagai pihak yang bersalah karena mengganggu kebebasan atau kenyamanan petutur. Pengakuan bersalah itu menimbulkan efek pelunakan daya ilokusi, yaitu penutur terkesan rendah hati sehingga tindak tutur itu dirasakan santun.

Cara berperilaku sopan dalam tindak tutur menyuruh dengan strategi basa-basi pembebasan berupa menyatakan aturan umum adalah seperti contoh (13).
(13) (a) Jagalah kebersihan!

(b) Buanglah sampah di tempat yang sudah disediakan!

(c) Kurangi kecepatan!

Tindak tutur (13a) dilakukan oleh atas nama dinas kebersihan kota. Tindak tutur ini diungkapkan dalam bentuk tulisan yang ditempel di dinding bangunan pasar, kantor, tempat ibadah, sekolah, taman kota, dan lainlain. Tindak tutur (13b) dilakukan oleh atas nama dinas kebersihan kota juga. Tindak tutur ini juga diungkapkan dalam bentuk tulisan yang ditempel di dinding kotak sampah yang terletak di taman kota, pasar, kantor, tempat ibadah, sekolah, dan tepi jalan.Tindak tutur (13c) dilakukan atas nama Dinas perhubungan dan LLAJR. Tindak tutur ini juga diungkapkan dalam bentuk tulisan yang dipasang di papan nama di jalan yang menikung tajam, persimpangan yang ramai, atau jalan yang licin. Tindak tutur menyuruh (13a), (13b), dan (13c) dilakukan dalam bentuk aturan umum yang ditandai dengan penggunaan ungkapan yang tidak tertuju orang tertentu saja atau pihak tertentu saja, misalnya jagalah kebersihan dalam tindak tutur (13a), Buanglah sampah di tempat yang sudah disediakan dalam tindak tutur (13b), dan ungkapan kurangi kecepatan dalam tindak tutur (13c).

Dalam tindak tutur (13a), penutur bermaksud menyuruh semua orang di lokasi untuk menjaga kebersihan. Dalam tindak tutur (13b), penutur menyuruh semua orang yang ada di lokasi itu untuk membuang sampah di tempat sampah yang sudah disediakan. Dalam tindak tutur (13c), penutur menyuruh semua orang yang menggunakan jalan di lokasi itu untuk mengurangi kecepatan.

Penutur menggunakan basa-basi penggunaan aturan umum kepada petutur, yaitu dengan ungkapan yang tidak 
hanya tertuju kepada orang tertentu atau pihak tertentu membentuk kesan penutur tidak pilih kasih. Perilaku tidak pilih kasih itu menimbulkan efek pelunakan daya ilokusi karena daya itu menyebar ke semua orang atau ke semua pihak dan mengenakkan hati petutur sehingga tindak tutur itu dirasakan santun.

\section{SIMPULAN}

Kesopanan berbahasa merupakan peranti bahasa yang digunakan untuk meminimalkan jatuhnya muka (citra diri) pelaku tutur. Ada dua cara utama yang dilakukan oleh penutur bahasa Indonesia untuk membentuk tindak tutur direktif yang santun, yaitu (1) menyuruh dengan basa-basi pengakraban dan penganjungan, (2) menyuruh dengan basa-basi peminimalan paksaan dan beban. Cara basa-basi pengakraban dan penganjungan mempunyai subcara, yaitu (a) basa-basi menggunakan penanda identitas sebagai anggota kelompok yang sama, (b) melibatkan penutur dan petutur dalam kegiatan yang sama, (c) mencari kesepakatan, (d) saling membantu, (e) bergurau. Cara menyuruh dengan basa-basi peminimalan paksaan dan beban mempunyai subcara (a) menyuruh secara tidak Langsung, (b) menggunakan pagar, (c) menggunakan syarat (d) meminimalkan permintaan kepada petutur, (5) meminta maaf atau izin, dan (e) menyatakan sebagai aturan umum.

Basa-basi pengakraban dan penganjungan berdampak pada pelunakan daya ilokusi sehingga petutur merasa diterima dan dihargai oleh penutur. Perilaku penutur itu menyenangkan hati petutur sehingga tindak tutur itu dirasakan santun. Basa-basi peminimalan paksaan dan beban berdampak pada pelunakan daya ilokusi sehingga petutur merasa tidak dihalang-halangi atau tidak dihambat dalam melaksanakan kehendaknya. Perilaku penutur seperti itu juga menyenangkan hati petutur sehingga tindak tutur itu dirasakan santun.

\section{UCAPAN TERIMA KASIH}

Artikel ini terwujud berkat bantuan dari berbagai pihak. Penulis mengucapkan terima kasih kepada semua pihak yang bersedia menyumbangkan data untuk artikel ini. Secara khusus, penulis mengucapkan terima kasih kepada narasumber dan mahasiswa peserta perkuliahan Pragmatik yang membantu pengumpulan data untuk artikel ini. Penulis juga mengucapkan terima kasih kepada Bapak/Ibu teman sejawat yang telah memberikan kritik dan saran untuk kesempurnaan tulisan ini. Penulis juga mengucapkan terima kasih kepada Ketua Jurusan Bahasa dan Sastra Indonesia, Dekan FBS UNP, Rektor UNP dan Ketua Lembaga Penelitian UNP yang telah memberikan berbagai fasilitas untuk dapat diselesaikannya artikel ini.

\section{DAFTAR PUSTAKA}

Austin, J. L. 1962. How to Do Things with Words. New York: Oxford University Press.

Azis, E. Aminudin. 2003. Realisasi Kesantunan Berbahasa Antargenerasi dalam Masyarakat Indonesia. Di dalam Bambang Kaswanti Purwo (ed.). PELLBA 16. Halaman 239-278. Jakarta: Pusat Kajian Bahasa dan Budaya Unika Atma Jaya.

Brown, Roger dan Albert Gilman. The Pronouns of Power and Solidarity. Di dalam Joshua A. Fishman (Ed.). Reading in the Sociology of Language. Hal. 252-275. Paris: Mouton.

Brown, Penelope dan Stephen C. Levinson. 1987. Politeness: Some Universals in Language Usage. Cambridge: University of Cambridge Press. 
Blum-Kulka, Shoshana. 1987. Indirectness and Politeness in Request: Same or Different? Journal of Pragmatics II. 131-146.

Gunarwan, Asim. 1992. Persepsi Kesantunan Direktif di dalam Bahasa Indonesia di antara Beberapa Kelompok Etnis di Jakarta. Di dalam Bambang Kaswanti Purwo (ed.). PELLBA 5: Bahasa Budaya. 179-215. Jakarta: Lembaga Bahasa Unika Atma Jaya.

Gunarwan, Asim. 1994. Kesantunan Negatif di Kalangan Dwibahasawan Indonesia-Jawa di Jakarta: Kajian Sosiopragmatik. Di dalam Bambang Kaswanti Purwo (ed.). PELLBA 7: Analisis Klausa, Pragmatik Wacana, dan Pengkoputeran Bahasa. Halaman 81-121. Jakarta: Lembaga Bahasa Atma Jaya.

Gunarwan, Asim. 2000. Tindak Tutur Melarang di Kalangan Dua Go- longan Etnis Indonesia: ke Arah Kajian Etnopragmatik. Di dalam Yassir Nasanius dan Bambang Kaswanti Purwo PELLBA 13. Halaman : 1-37. Jakarta: Lembaga Bahasa dan Budaya Universitas Atma Jaya.

Ibrahim, A. Syukur. 1996. "Bentuk Direktif Bahasa Indonesia". Disertasi. Universitas Erlangga.

Leech, Geoffrey. 1983. Principles of Pragmatics. London : Longman.

Mualimin. 2003. Kesantunan Direktif dalam Surat Bisnis: Kajian Penggunaan Ungkapan Permohonan Bahasa Inggris oleh Penutur Bahasa Indonesia. Di dalam Jurnal Bidang Kebahasaan, Kesusasteraan, dan Kebudayaan, 27. 1: 11-19.

Searle, John R.1975. Indirect Speech Act. Di dalam P. Cole dan J. Morgan(ed.). Syntax and Semantics Vol. 3: 59-82. 